\title{
Withdrawal of the Partner and Its Consequences in Albanian Company Law
}

\author{
Phd candidate Erjola Aliaj \\ European University of Tirana \\ Email:aerjola@gmail.com
}

Doi:10.5901/ajis.2014.v3n6p307

\section{Abstract}

\begin{abstract}
Referring to the legal and doctrinal concept of commercial companies in general and especially of the limited liability company, the commercial company constitutes a contract between its founders, who join their assets (goods) or services. The founders undertake commercial risk in order to develop a profitable commercial activity, aiming the periodical distribution of profit in the form of dividends. Albanian Law No.9901 dt.14.04.2008 on "Entrepreneurs and Commercial companies" especially regulates the "withdrawal of partners" as one of the classical methods of ceasing the capacity of the partner for the limited liability companies which was not treated in the old law and often conflicts between partners lead to dissolution of the company. In general, this method of ceasing the capacity of partner constitutes a partial termination of this contract/legal relationship for the founding of the company. In the present research paper, through a critical analysis, particular attention has been paid not only to the legal provisions, which treat this method of ceasing - its reasons, procedure and consequences but also to the legal ambiguity and lack of legal treatment identified, for which there may be offered possible solutions.
\end{abstract}

Keywords: limited liability company, withdrawal, partner, quotas' liquidation.

\section{Introduction}

The present research paper consists of three chapters. Subject of the first chapter is the concept of partner's withdrawal in the limited liability company and the critical analysis of the legal provisions, which treat the reasons of partner's withdrawal. The second chapter gives a description of the partner withdrawal procedure in the limited liability company. The last chapter deals with the consequences of the partner's withdrawal in the limited liability company. The three chapters are focused on the identification of uncertainties and gaps in treatment of the partner's withdrawal in commercial legislation and offering possible solutions to the problems identified.

\section{Causes of Withdrawal of Partners in Limited Liability Companies}

The commercial company, beyond adjustment of technical character of the method of its constitution, constitutes a contract between its founders. In the contract or the agreement for founding a commercial company, there must be present the following elements:

a) the purpose of the parties to enter into legal relationship;

b) their contribution;

c) the exercising of a joint commercial activity;

d) the goal to reach a profit for the partners. (Xhoxhaj, A., 2012)

Law no.9901 dated 14/04/2008 on "Entrepreneurs and commercial companies", in the same way as it disciplines the method of formation of limited liability companies, their establishment, the structure, the method of ceasing this commercial entity, has especially provided even the cases of loss of capacity of partner, participating in different legal entities subject to the law. More concretely, two of the most classical methods of ceasing the capacity of partner for the limited liability companies, in the terms of commercial law are:

1. voluntary withdrawal of the partner from the company (Recesso);

2. expulsion of the partner from the company (Esclusion).

As regards the first case, in the meaning of the commercial law we are dealing with an act of sole will of the partner of the company, who for certain reasons does no longer wants to be partner of the company. On the other hand, the withdrawal of the partner, viewed as a special provision of commercial law, constitutes an act of will from the main body of the company, the General Assembly of the partners, based on a certain quorum, in cases which constitute open violation by the side of the partner of the commercial law or of the statute of the company (Decision nr.8811, date 


\subsubsection{3, of Tirana District Court).}

Referring to the legal and doctrinal concept of the commercial company in general and especially to the limited liability company, in case of withdrawal of the partner in the limited liability company we are in front of a partial termination of the contract/relationship of the company due to the will of the partner (Ferri, G., 1987).

The legal right of the partner to withdraw from the company is his declaration of will to terminate the relationships with the company. This case seems as an exclusion from the general rule provided in article 690 of Albanian Civil Code, where the contract has the power of law for the parties and may be terminated only upon mutual consent of the parties. In case of withdrawal, the partner is recognized the right to withdraw from the company, by terminating the initial contract without approval of other partners. The contract of the company has a special nature, because the company continues its existence after withdrawal of one of the partners. (Xhoxhaj, A., 2012)

For the limited liability company the law provides to any partner to withdraw from the company for reasonable motives, which make it impossible and harmful for his interests the additional stay in the company. As reasonable motives, law "On Entrepreneurs and Commercial companies" in article 101 stipulates circumstances, which to the entirety of concrete facts prove that other partners or the company:

- $\quad$ have performed actions in damage of the partner, who wants to withdraw;

- have impeded the exercising of rights deriving from ownership over the quota of the partner, who wants to withdraw;

- $\quad$ has charged the partners in question with unreasonable liabilities;

- for other reasons, which make impossible the continuation of partnership.

The above mentioned reasons may include a wide range of topics. The allegations of the partner will be proved with facts case after case (Malltezi, A., 2011). As regards other reasonable motives for which it is allowed the withdrawal of the partner, in law it is not found any detailed definition regarding to what will be considered as such, therefore in the statute of the company may be described other causes, except for those provided by law. Also, by the partners themselves or the partners' assembly may be estimated other reasonable motives (Xhoxhaj, A., 2012).

The right of withdrawal of the partner from the company has been considered as a right, especially of the partner in minority, for being protected by the decisions of the partners' assembly with which he does not agree, or which differ in entirety with the contract/agreement for founding the company. The law "On entrepreneurs and commercial companies" does not provide any term for exercising the right of withdrawal of the partner from the limited liability company. Under these circumstances, the partner has the right of withdrawal at any time and the statute of the company may not restrict such right (Bachner, Th., \& Schuster, E., \&Winner, M. 2009).

\section{Procedure of Withdrawal of Partner in Limited Liability Companies}

The withdrawal of the partner is exercised through written declaration of his free will, which in essence is a unilateral juridical action, by means of which the partner decides to cease rights and liabilities he has undertaken by means of the agreement for establishing the company.

Under the article 101 clause 2 of the law on "Entrepreneurs and Commercial Companies" the partner must notify the company in writing and must lay out the reasons of withdrawal. Law does not provide details if the act of notification will be a simple letter, registered mail or notarial deed. Under these circumstances the letter may be simple for as long as the law does not provide a special form of the same (Xhoxhaj, A., 2012). The sufficient reasoning of this letter does not influence on the attitude of the partner in the company, because the law provides that any partner is free to decide whether to continue his activity in the company or not and the company may decide independently to claim in court exclusion of the partner; this reasoning influences in the financial consequences of the withdrawal (Malltezi, A., 2011).

The withdrawal from the company brings several consequences such as interruption of relationships with the company, reimbursement of contribution which the partner that is withdrawing from the company has given, interruption of the participation in meetings of the assembly. Lack of participation, in compliance with the article 89 point 1 of Law "On entrepreneurs and commercial companies" starts from the meeting, where it is decided for its withdrawal etc. (Bachner, Th.,\& Schuster, E.,\&Winner, M. 2009).

With regard to the effects of withdrawal, although are not explicitly provided in the law "On entrepreneurs and Commercial Companies" are immediate. In the law it is provided that the rights deriving from the quality of the partner in the company cease at the date of withdrawal. Thus, withdrawal of the partner has immediate effect and his rights in the company may cease at the moment of declaring the will of withdrawal, therefore he can no longer claim profits or for participating in the assembly meeting of partners, when has declared his withdrawal from the company. Additionally, the 
losses that company may suffer during its activity in this period may not affect the partner who has declared his will to terminate the contract of the company. (Xhoxhaj, 2012)

The notice for withdrawal is addressed to the administrator of the company, who in the meaning of article 101 point 3 of the law "On entrepreneurs and commercial companies" must immediately convene the meeting of partners' assembly.

One of the rights of the partner when withdrawing for reasonable motives, is the liquidation of his quota, in other words of his contribution in the capital of the company. The law itself does not specify any general rules when the compensation becomes applicable, so the parties try to include this amount in the agreement between the partner that is withdrawing and the general assembly. If the general assembly accepts the withdrawal and agrees with the partner who is withdrawing for the amount of compensation for his quota, there must be no court process (Bachner, Th., \& Schuster, E., \&Winner, M. 2009).

Additionally, in article 101 point 4 of the law "On entrepreneurs and commercial companies", the legislator has provided that the partner who is withdrawing, is entitled to claim to the court the profit for liquidation of the quota, in case it has not been reached an agreement with the general assembly. As per above, the partner who is withdrawing may bring a lawsuit if;

1) the general assembly is not convened even after the notice for withdrawal of the partner or when the general assembly does not make any valid decision (e.g., because it is missing the required quorum).

2) the general assembly does not recognize the claim of the partner that there exists a reasonable motive for his withdrawal.

In these cases, as per article 103 point 1 of law "On entrepreneurs and commercial companies" the withdrawal has consequences when the court takes final decision related to withdrawal (Bachner, Th., \& Schuster, E., \&Winner, M. 2009).

In practice it is often encountered the situation when the general assembly admits there exists reasonable motive for withdrawal, but opposes the amount of required compensation by the partner for the value of his quota. Regardless of the fact that this last case is not explicitly mentioned in article 101 point 4 of the law "On entrepreneurs and commercial companies", may be estimated that the partner is entitled to bring a lawsuit to the competent court. Otherwise, it would be very easy for other partners to impede the withdrawing partner to exercise his right to address to the court for recognizing such withdrawal and at the same time for assigning an appropriate compensation, by frustrating this way the economic motives of withdrawal (Bachner, Th., \& Schuster, E., \&Winner, M. 2009).

\section{Consequences of Withdrawal of the Partner in Limited Liability Companies}

In all cases in which the relationship of the company is interrupted due to the withdrawing partner, his quota will be liquidated, except for the case when his contribution has been completely missing.

In article 103 point 1 of the law "On entrepreneurs and commercial companies", it is provided the ceasing of right of partnership and not for any potential transfer of this right to other partners. Therefore, the right of partner to be compensated for the amount of his quota is indeed addressed to the company and may oblige him to liquidate some of its assets, in order to increase the amount of stock money.

The law is very obscure as regards the details of this compensation for the value of the quota; such compensation in Article 101 point 3 and point 4 is called "liquidation of quota". In the framework of a separate legal personality of the company, such "liquidation of quota" may not mean total (or partial) liquidation of the company, and from it derives that the withdrawing partner may not claim his quota in the assets of the company, to which the partner has no rights, but only the compensation by the company of the value of his quota. (Bachner, Th., \& Schuster, E., \&Winner, M. 2009).

As per above, in law it is not mentioned how will be performed the liquidation of the quota, the procedures and terms of such liquidation.

The quota in the capital of a limited liability company includes the entirety of subjective rights of ownership that the partner has on the registered capital of the company. Such entirety of rights is evidenced by the contributions of the partners in the capital of the company, which have an economic value expressed in money (Bachner, Th., \& Schuster, E.,\&Winner, M. 2009). The value attributed to all contributions of the partners constitutes the founding capital of the company (Ferrara, F., \& Corsi, F., 2011). Such capital is distinguished from its own capital of the company, which constitute the entire estate of the company established during exercising its business activity. The feature of the estate is its increasing or decreasing ongoing changeability depending on the progress of the activity of the commercial company. Whereas, the founding capital does not change, unless in cases provided by law or statute, when it is continued with 
increase or decrease of the capital. In other words, the capital of the company differs from the contributions of the partners. As consequence, the value of the quota for the liquidation will be provided based on the value of the capital of the company at the time of the withdrawal of the partner. (Ferrara, F., \& Corsi, F., 2011)

If we were in front of the case of withdrawal of the partner with a big quota, the company would encounter difficulties in providing such big amount of cash money. In most of the cases, an active business does not save big amounts of stock cash, as the cash investments tend to be an unproductive investment in the capital of the partners. In this context, given that the law does not provide any term in liquidation of the quota, the necessity to collect big amount of cash money, may cause serious disruption in the activity of the company and may even lead it to a bankruptcy condition. In terms of a normal exercising of economic activity, any company, based on article 77 of the law "On entrepreneurs and commercial companies", for the compensation of the quota of the withdrawing partner, the assets of the company should totally cover its liabilities and the company should have sufficient circulating assets to pay the liabilities becoming due in the 12 next months (which should be proved by an insolvency certificate issued by the administrators). In case that the company is not able to fully meet such criteria for the whole amount of compensation for the value of the quota of the withdrawing partner, the only possible solution is that the compensation to be done by installments within a period of time -with the risk for the partner who is withdrawing that the company will bankrupt during this time, but this is a consequence of the function for defending the creditors of article 77 of law "On entrepreneurs and commercial companies"(Bachner, Th.,\& Schuster, E.,\&Winner, M. 2009).

If the partners have contributed in kind, the liquidation of their quota in case they will claim to take the goods they have given in the company, it is quite impossible for as long as these goods have been transferred on behalf of the company. The situation would be different if these goods have been only given for utilization to the company, by enabling the return of the contribution in kind to the withdrawing partner.

The compensation for the value of the quota of the partner should be separated from other types of rewards mentioned in article 101 of the law "On entrepreneurs and commercial companies". According to article 101 point 5 of the law "On entrepreneurs and commercial companies", if a partner of a company incurs damage to the company through his withdrawal, due to lack of reasonable motives, he must indemnify the company for such incurred damage. Given that without a reasonable motive there cannot be a valid withdrawal, the expected damage may be only linked to the expenses for legal advice and organization of the meeting of the general assembly as per article 101 point 3 of the law "On entrepreneurs and commercial companies". Also, the company may even recover the indemnification for the incurred damages by the lost business opportunities, e.g., missing profits of an interrupted project, in special circumstances when the notice by the partner for his intention to withdraw (without reasonable motives) has caused failure of the negotiations. According to article 101 point 6 of the law "On entrepreneurs and commercial companies", the withdrawing partner may claim compensation jointly by the partners for any damage caused to him by the company or by other partners who lead to his withdrawal. Such indemnification is claimed in addition to the compensation for the value of the quota of the partner, but both types of compensation may not lead to a double remedy of the same damage. This would be the case if the estimation of the quota calculates the amount of reward towards the company on behalf of a damage incurred by another partner (Bachner, Th.,\& Schuster, E.,\&Winner, M. 2009).

\section{Conclusions/Recommendations}

Given that in law "On entrepreneurs and commercial companies" it is not found any detailed description to what will be considered other reasonable motives of withdrawal of the partner, the partners should define in their statute of the company other well described motives, by minimizing the conflicting situations amongst them.

Taking in consideration that the law "On entrepreneurs and commercial companies" does not provide any term for exercising the right of withdrawal of the partner from the limited liability company, then the partner may be entitled to withdraw at any time and the statute of the company shall not impede him from this right.

The Law "On entrepreneurs and commercial companies" does not provide details if the act of notification for withdrawal is a simple letter, registered mail or notarial deed. Under these circumstances, the letter may be simple for as long as the law does not provide any special form of the same.

As regards the effects of withdrawal, although in the law "On entrepreneurs and commercial companies" are not explicitly provided, they are immediate. In the law it is provided that the rights deriving from the quality of the partner in the company cease at the date of withdrawal. Therefore the withdrawal of the partner has immediate effect and his rights in the company shall cease at the time when he declares with his will to withdraw, therefore he may not claim any profits or to participate in any meetings of the partners assembly when has declared his withdrawal from the company. 
One of the rights of the partner when withdrawing for reasonable motives, is the liquidation of his quota, in other words of the contribution he has given in the capital of the company. The law "On entrepreneurs and commercial companies" does not specify any general rules when the liquidation becomes due, how will the liquidation be performed and which will be the procedure to the followed. Under these circumstances the parties shall try to include this amount in the agreement between the partner who is withdrawing and the general assembly. This right of the partner to be compensated for the value of his quota will be addressed to the company and may oblige it to liquidate some of its assets, in order to increase the amount of stock money. The value of the quota for liquidation will be contemplated based on the value of the capital of the company at the time of withdrawal of the partner.

In case that the company shall not be able to fully repay the amount of compensation for the value of the quota of the withdrawing partner, the only possible solution is that the compensation to be done by installments within a specified period of time

\section{References}

\section{Court decisions}

Decision no.8811, dated 29.07.2013 of Tirana District Court

\section{Legislation}

Law No. 9901, dated 14.04.2009, "On Entrepreneurs and Companies"

\section{Monographies}

Bachner, Th., \& Schuster, E., \& Winner, M. (2009). The new Albanian law "On companies" interpreted according to its sources in European law. Dudaj publications.

Dine, J., \& Blecher, M., \& Hoxha, Sh., \& Race, B. (2008). The New Law on Entrepreneurs and Companies - Commentary.

Ferrara, F., \& Corsi, F. (2011). Gli imprenditori e le società. Milano.

Ferri, G., (1987). Le società. Torino

Malltezi, A. (2011). Albanian law of commercial companies. Mediaprint publishing house.

Xhoxhaj, A. (2012). Adjudication of issues related to organization and operation of Limited Liability Company - Dissertation. 
